\title{
FEJLESZTÉSI IRÁNYOK AZ ANYAGMOZGATÁS-TERVEZÉSBEN
}

\author{
Telek Péter \\ egyetemi docens, Miskolci Egyetem, Logisztikai Intézet \\ 3515 Miskolc, Miskolc-Egyetemváros, e-mail: alttelek@uni-miskolc.hu
}

\begin{abstract}
Absztrakt
Az anyagmozgató rendszerek tervezése bonyolult feladat, aminek oka elsösorban a kiszolgálási változatok és a kiszolgált technológiák sokféleségében, ill. a sztochasztikusan változó kiszolgálási igényekben rejlik. Az anyagmozgatás tervezési feladatok sokfélesége miatt ez különbözö szoftverek alkalmazását igényli. A cikkben bemutatott kutatás egy olyan általános tervezési séma kidolgozását célozza meg, amivel ezt a problémát egyszerüsiteni lehet. A téma részletes feltárása után bemutatásra kerül az ún. folyamat alapú anyagmozgatás tervezési algoritmus, amely az integrált tervezési folyamat lépéseit felhasználva próbál egy áttekinthetőbb, kevésbé komplex megoldási sémát megvalósitani. A cikk a témában eddig megjelent kutatási eredményeket foglalja össze.
\end{abstract}

Kulcsszavak: anyagmozgatás, anyagáramlási relációk, folyamatképzés, folyamat alapú tervezés

Abstract

Planning of material handling systems is a difficult task, because of the large number of the handling variations, technology processes and the stochastic changing demands. In generally, the different planning tasks require different computer software. The research, presented in this paper, targeted to develop a planning concept which can help to reduce the complexity of the general integrated planning process. After the detailed overview of the problem, we present the algorithm and the published results of the process-based planning of material handling. The described method uses the steps of the integrated planning process, however gives a followable, less complex solution scheme. This paper summarizes the published results of the researches related to this topic.

Keywords: material handling, handling relations, process building, process-based planning

\section{Bevezetés}

Az anyagmozgató rendszerek tervezése rendkívül komplex terület. Ennek oka elsősorban a kiszolgálási változatok és a kiszolgált technológiák sokféleségében, ill. a sztochasztikusan változó kiszolgálási igényekben rejlik. A feladat komplexitása miatt rendkívül nagy feladat hárul a logisztikai szakemberekre, amit célszerü lenne korszerü számítógépes módszerekkel támogatni. Sajnos az anyagmozgatás tervezési feladatok sokfélesége ez több, különböző szoftver alkalmazását igényli.

A cikkben ismertetett kutatás egy olyan általános tervezési séma kidolgozását célozza meg, amivel ezt a problémát egyszerüsíteni lehetne.

A probléma részletes feltárása után bemutatásra kerül az ún. folyamat alapú anyagmozgatás tervezési algoritmus, amely az integrált tervezési folyamat lépéseit felhasználva próbál egy áttekinthetőbb, kevésbé komplex megoldási sémát megvalósítani. 


\section{Anyagmozgató rendszerek tervezése}

Anyagmozgató rendszerek tervezése során egy komplex anyagáramlási feladathoz keresünk megfelelö kiszolgáló berendezéseket és összehangoljuk azok müködését [1]. A megoldást kereshetjük feladatszemléletű, vagy rendszer-szemléletü megközelítéssel.

Rendszer-szemléletű megközelítésnél a rendszer egészét vizsgáljuk és a rendszerelemek közötti kapcsolatok alapján keresünk megoldást [2]. Ilyen esetekben a rendszerek hasonlósága alapján történik a tervezés, ami megnyilvánulhat objektumokban, kiszolgáló eszközökben, anyagmozgatási feladatokban, kiszolgált technológiában, stb. A tervezés során egy, a kialakítandó rendszerhez hasonló, már müködő kiszolgáló rendszert kell keresni, és annak jellemzőit adaptálni az új feladatra. Jellemző felhasználási területe az azonos funkciójú és felépítésủ (gyártó) üzemek telepítése különbözö helyeken (pl. multinacionális cégek leányvállalatai) [3].

A feladat-szemléletü tervezés különálló anyagmozgatás-tervezési lépések (telepítés tervezés, eszköz-tervezés, egységrakomány-képzés tervezés, stb.) adott sorrendü, vagy iteratív megoldását jelenti [1]. A feladat-szemléletủ tervezés a gyakorlatban három különböző formában alkalmazható:

- egy adott feladat egyedi, vagy kiterjesztett megoldása,

- komplex tervezés,

- integrált tervezés.

Az egyedi feladatok megoldására alaposan kidolgozott, specifikus módszerek, ill. szoftverek állnak rendelkezésre [4], de az eredmény csak az adott feladat szempontjából optimális, a tervezés más lépéseit nem veszi figyelembe. Kiterjesztett megoldásról akkor beszélünk, ha a tervezés során egy adott feladatot oldunk meg, de más feladatok paramétereit is figyelembe vesszük (pl. járattervezés során az egységrakomány-képző eszköz (ERKE) jellemzők hatását is vizsgáljuk).

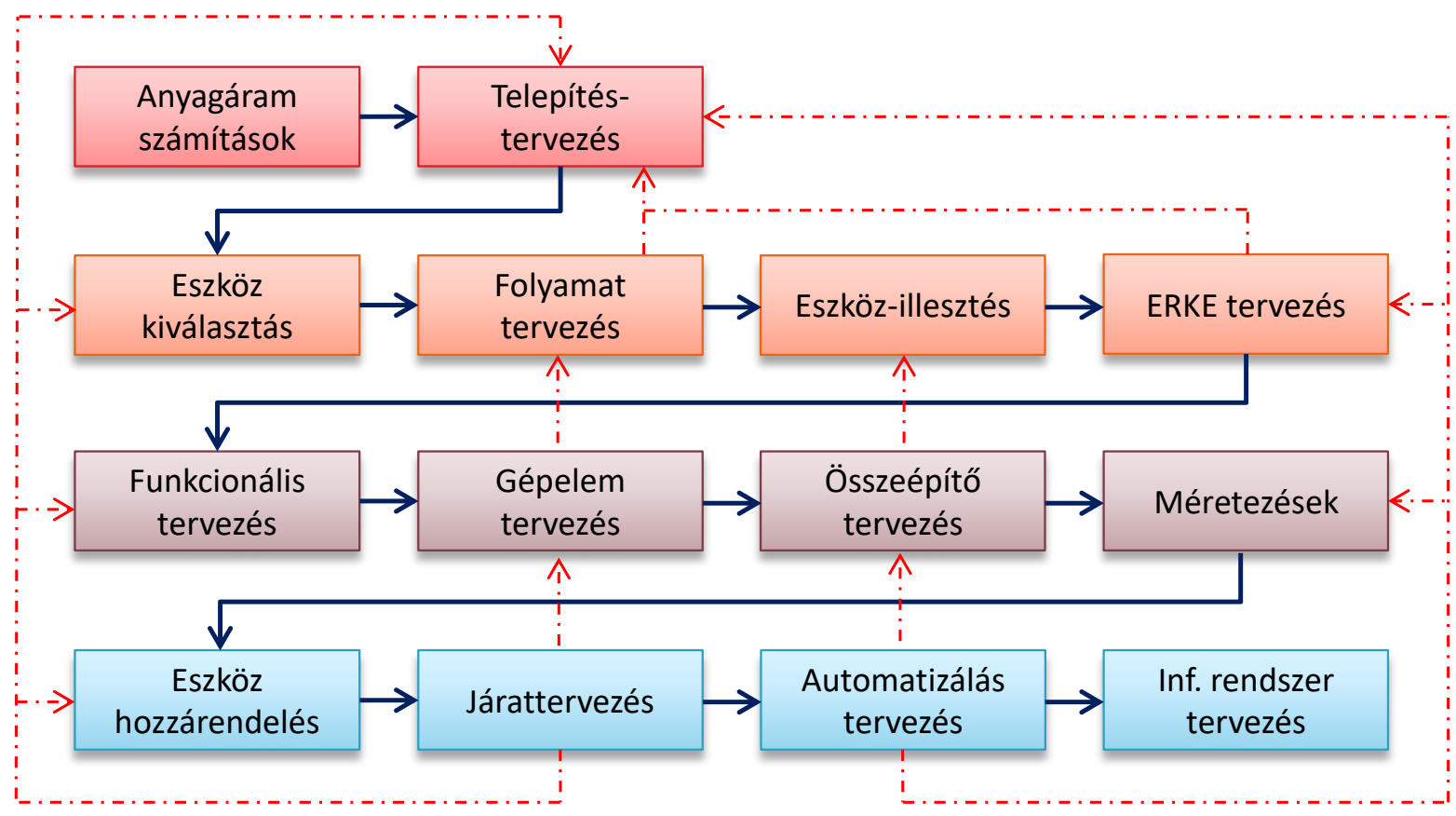

1. ábra. Az integrált tervezés folyamata [1]. 
Komplex tervezés során több feladatot (legtöbbször 2-3) oldunk meg iteratív módon, de korlátozott komplexitás mellett. A tervezési feladatokat általában egy adott aspektus mentén integráljuk. A tervezés bonyolultsága az egyes feladatok komplexitásának függvénye [5].

Integrált anyagmozgatás tervezés esetén egyidejüleg minden feladat megoldásra kerül, de ez a feladatok nagy száma, komplexitása és az iteratív megoldási séma (1. ábra) miatt csak egyszerü rendszereknél alkalmazható [6].

A különböző tervezési feladatok eltérő paraméterek, ill. paraméter-kapcsolatok, módszerek és eljárások felhasználását igénylik, ezért a megoldáshoz szükséges, korszerű számítógépes eljárások is különböznek, melyek a következő főbb kategóriákba sorolhatók [7]:

- CAD tervező rendszerek,

- tudásbázisú rendszerek,

- szimulációs eljárások,

- Virtuális Valóság,

- Optimalizáló módszerek.

\section{Az anyagmozgatás-tervezés problémái}

Az anyagmozgató rendszerek, hasonlóan a müszaki területek többségéhez, hatalmas változáson mentek keresztül az elmúlt évtizedekben. Nemcsak az iparban, hanem a rohamosan fejlődő szolgáltatási folyamatokban is egyre több, egyre bonyolultabb kiszolgálási feladatot kell megoldani. Ennek köszönhetően az anyagmozgatás tervezésének is újabb, bonyolultabb feladatokkal kell szembenéznie, amelyek megoldásához korszerü technikákra, eljárásokra és szoftverekre van szükség.

Az ellátási lánc kiterjedésének és a kiszolgálási feladatok komplexitásának növekedése következtében a kiszolgáló rendszerek jelentősége megnőtt, összevetve a néhány évtizeddel ezelötti alárendelt szereppel. A jelenlegi ipari és szolgáltatási folyamatokban számottevő megtakarítás, ill. jelentős hatékonyságnövekedés érhető el az optimális kiszolgáló rendszerek alkalmazásával, ezért az anyagmozgatás-tervezési módszerek kiemelt szerepet játszanak az új, ill. a meglévő gyártási folyamatok kialakítása és müködtetése során.

A folyamatosan változó, komplex gyártási környezet és a sztochasztikus fogyasztói igények miatt az anyagmozgatás tervezése rendkívül összetett feladat, amely során az előző fejezetben felvázolt tervezési koncepciók alkalmazása sok energiát és időt igényel a logisztikus szakemberektől.

A gyakorlatban előforduló tervezési feladatokat a megoldáskeresés szempontjából különböző csoportokba sorolhatjuk, amelyek az egyszerü, az összetett és a komplex feladatok (1. táblázat). Egyszerü feladatok esetén a tervezést legtöbbször gyakorlati tapasztalatokon alapuló, józan megfontolások alapján végzik el. Összetett feladatoknál a tervezés a meglévő sémák felhasználásával, de jelentős munkabefektetéssel végezhető el, ahol az egyes tervezési feladatok megoldására szolgáló szoftverek is felhasználhatók. Komplex feladatok esetén az optimális megoldás megtalálása általában problémát jelent. Segíthet a megoldási változatok korlátozása, ami csökkentheti a hatékonyságot (lokális optimum), ill. heurisztikus módszerek alkalmazása, ami jelentős számítástechnikai kapacitásokat igényelhet.

A fenti lehetőségek sokszor nem elégítik ki a korszerü gyártási rendszerek által megfogalmazott igényeket, ezért új megoldások keresésére van szükség.

2020-ban vizsgálatokat végeztünk a Science Direct adatbázisban található, anyagmozgatási kutatásokkal foglalkozó publikációkról [7], amelyben többek között feltártuk az anyagmozgatás tervezésével kapcsolatos tématerületeket is. 
1. táblázat. A tervezési feladatok komplexitási jellemzői [6]

\begin{tabular}{|l|c|c|c|}
\hline \multirow{2}{*}{ PARAMÉTER } & \multicolumn{3}{|c|}{ TERVEZÉSI FELADAT } \\
\cline { 2 - 4 } & Egyszerü & Összetett & Komplex \\
\hline 1. Eszköz típus & $e g y$ & kevés & sok \\
\hline 2. Eszközszám & kevés & nagy & sztochasztikus \\
\hline 3. Anyagáramlás & determinisztikus & jól közelithetö sztochasztikus & közvetlen, közvetett \\
\hline 4. Relációk & közvetlen & közvetlen & párhuzamos \\
\hline 5. Hozzárendelés & soros & soros, kismértékben párhuzamos & natisztikus, \\
\hline
\end{tabular}

Megállapítottuk, hogy a 2006 és 2019 között közreadott tudományos cikkek között egyetlen olyan publikáció található [8], amely integrált módon közelíti meg az anyagmozgatás tervezést, de csak áttekintő jelleggel, nem ad új megoldást. A megvizsgált $317 \mathrm{db}$ tudományos közlemény $89 \%$-a egy tervezési feladat megoldásával foglalkozik. 2,5\% használ kiterjesztett megközelítést és $8,2 \%$ integrál két különböző tervezési feladatot [7] (2. ábra).
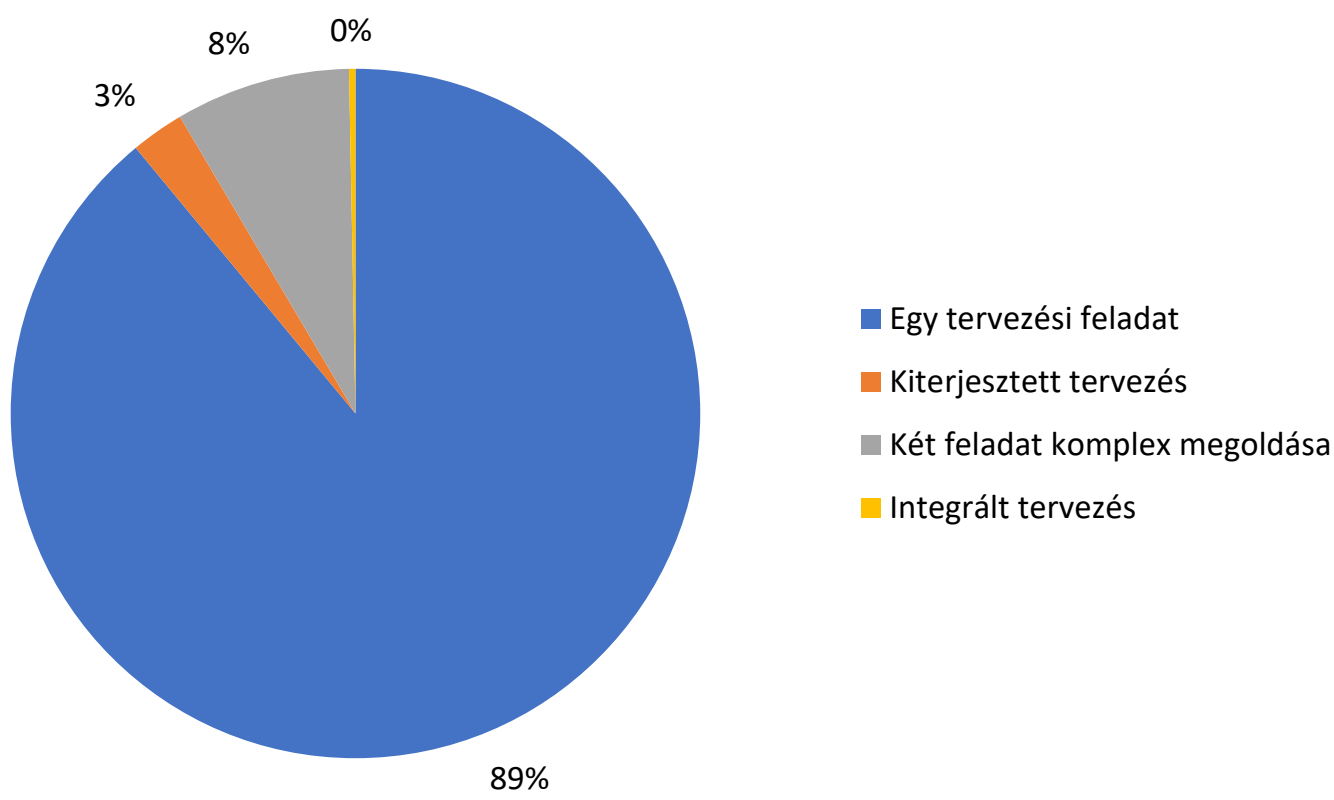

2. ábra. Anyagmozgatás-tervezési feladatok megoszlása a Science Direct adatbázisban [7]. 
A 2. ábrából egyértelmüen kitünik, hogy a kutatók sem preferálják az integrált tervezést, elsősorban annak komplexitása miatt, az esetek nagy részében egy-egy tervezési feladat megoldására koncentrálnak. Ez a hozzáállás bizonyos esetekben megfelelő eredményt hozhat, de az anyagmozgatás különböző aspektusaival foglalkozó cégek egyre többször találkoznak olyan iparvállalatokkal, akik azért nem fogadják el a felkínált technikai, informatika vagy rendszermegoldásokat, mert nem látják egyértelmüen a teljes folyamatra gyakorolt hatásukat.

Ilyen, a kiszolgálási folyamat teljes egészére vonatkozó információkat csak az integrált megközelítés alkalmazásával lehet kinyerni. Ebből látszik, hogy egyre nagyobb az igény az integrált tervezési módszerekre.

A számítástechnikai teljesítmények növekedésével, ill. az optimálási módszerek fejlődésével elvileg lehetővé válik egy olyan szoftver-rendszer megalkotása, amely képes lehet az integrált tervezés megvalósítására, eleinte az egyszerübb, majd egyre összetettebb rendszereknél.

Ez a tendencia előrevetíthet egy lehetséges fejlesztési irányt, de két alapvető probléma megkérdőjelezi annak létjogosultságát: a kialakítandó rendszer bonyolultsága, ill. a szoftver-rendszer áttekinthetősége.

Mivel a tervezési részfeladatok jelentős része önmagában is bonyolult (pl. járattervezés), ezért ezek integrálása, ill. a jövőben a kiszolgálási feladatokban jelentkező komplexitás növekedés hatásai miatt kérdés, hogy egyáltalán megvalósítható-e egy általános eljárás kifejlesztése? Amennyiben a szoftver csak korlátozott esetekben lesz alkalmazható, akkor pedig kérdés, hogy megéri-e a befektetett jelentős munkát.

A másik probléma a módszer követhetősége. Egy általános fogyasztói szoftver esetén a használók nem tudják, de nem is akarják követni a megoldási folyamatokat, ezért nem zavarja őket a „feketedoboz" effektus. Ipari alkalmazásoknál ez már nem ilyen egyszerü, hiszen a müködés követése és az esetleges változtatások következményeinek megértése alapvető szükséglet a szakemberek számára. Egy nagyon komplex szoftver esetén nehéz követni a müködést és abból következtetést levonni a változtatásokkal kapcsolatban, ezért a szakemberek könnyen bizalmatlanok lehetnek a szoftverekkel szemben, ami gátolhatja azok elterjedését [9].

A fenti problémák miatt merült fel egy teljesen új fejlesztési irány, ami egy más oldalról közelíti meg az anyagmozgatás tervezést és négy alapvető követelménynek igyekszik megfelelni:

- általános, integrált tervezést valósítson meg,

- tegye lehetővé az egyes feladatokra eddig kifejlesztett módszerek beillesztését,

- csökkentse a tervezési folyamat bonyolultságát és

- legyen áttekinthető a tervezés folyamata.

\section{Folyamat alapú tervezés}

A folyamat alapú tervezés gyökerei 2013-ig nyúlnak vissza, amikor az integrált tervezés komplexitásának csökkentésére kifejlesztettük az ún. eszköz-előtervezés koncepcióját [6]. Ez a koncepció azzal próbálta egyszerüsíteni a tervezést, hogy kiemelte az anyagmozgató eszközök kiválasztását az integrált tervezési folyamat elemei közül, így az integrált lépéseket csak néhány eszközváltozatra kellett végrehajtani. A koncepció finomítása során részletesen elemeztük az anyagmozgató gépek jellemzőit és megvizsgáltuk hatásukat a kiválasztási folyamatra [10]. Az integrált tervezési elemek fejlesztése során kutatásokat folytattunk a számítógépes megvalósítás lehetőségeivel [11] és az anyagáramlási relációk meghatározásával kapcsolatban is [12]. 
Ilyen elözmények után, 2018-ban született meg a folyamat alapú tervezés koncepciója [13], amelynek célja az egész integrált tervezési folyamat egyszerüsítése az eszköz-előtervezésnél alkalmazott logika mentén. Az egyszerüsítés következményeként a módszer nem a globális optimumot célozza meg, hanem csak egy, a célfüggvényeknek leginkább megfelelő megoldást keres egy követhető folyamattal.

A folyamat alapú tervezés során a feladat-szemléletü tervezési lépéseket alkalmazzuk, de egy előre definiált, egyszerü algoritmus mentén (3. ábra). A tervezés 4, egymástól elkülönülő fázist tartalmaz, amelyek adott paraméterek alapján különböző jellemzőket állítanak elő [14]:

1. Anyagáramlási relációk tervezése

2. Anyagmozgató eszközök előtervezése

3. Kiszolgálási folyamatok tervezése

4. A rendszer müködtetésének tervezése

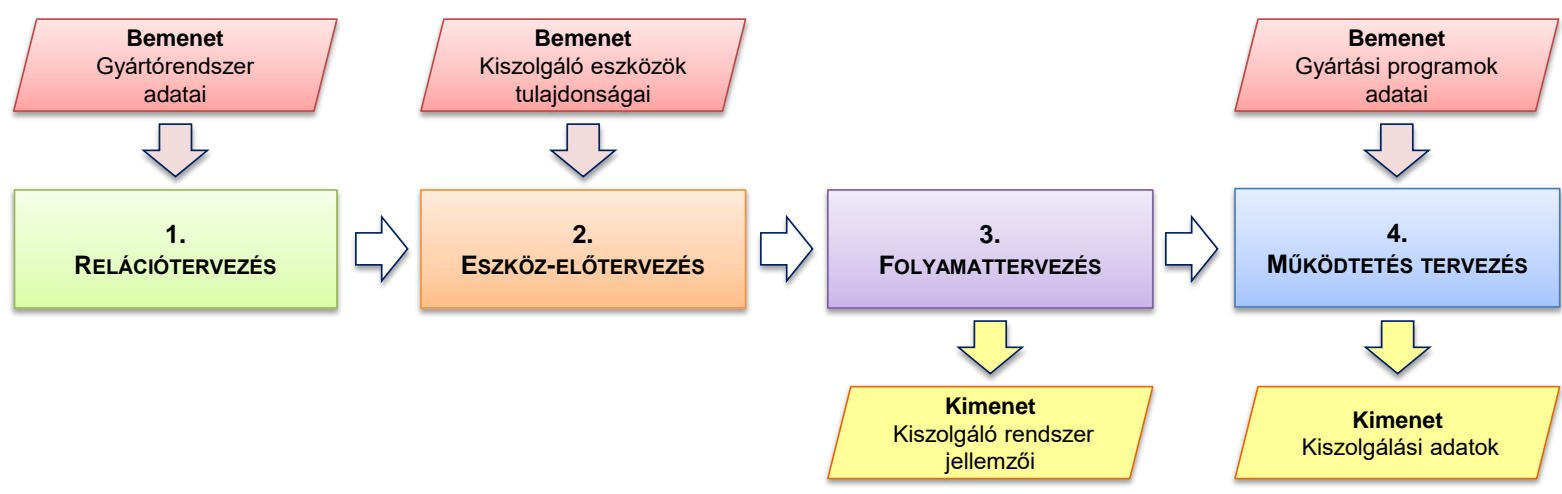

3. ábra. A folyamat alapú tervezés algoritmusa [14].

A relációtervezés során történik a kiszolgálási tevékenységeket leíró matematikai paraméterek meghatározása és hozzárendelése az objektum kapcsolatokhoz, a gyártórendszer jellemzői és a gyártási adatok alapján. Az eszköz-előtervezés segítségével korlátozhatjuk a tervezés további fázisaiban vizsgált anyagmozgató berendezés-típusok számát, jelentősen csökkentve a folyamat komplexitását. A lépés célja, hogy a berendezések és az anyagáramlási feladatok tulajdonságainak összehasonlításával kiválasszuk a leginkább alkalmas géptípusokat [6]. A folyamattervezés az anyagáramlási relációk adott logikán alapuló összekapcsolását jelenti, amely figyelembe veszi az alkalmazható kiszolgáló berendezések, ill. a technológiai folyamatok sajátosságait is. A folyamattervezés eredményeként elóáll egy olyan anyagmozgató rendszer, amely alkalmas a gyártási folyamatok kiszolgálására. A múködtetés-tervezés a folyamat befejező fázisa, ahol a kiszolgálási feladatok és eszközök ütemezése, ill. végső kialakítása történik.

Fontos feladat definiálni, hogy a folyamat alapú tervezés miben különbözik az általános integrált tervezési folyamattól. A 4. ábrán látható, hogy az új algoritmus hogyan integrálja az egyes tervezési lépéseket.

A 4. ábra alapján kijelenthetö, hogy a folyamat alapú tervezés egy általános és integrált anyagmozgató rendszer tervezési módszer. Mivel az egyes feladatok közötti kapcsolatok és esetleges iterációk csak a fő fázisokon belül realizálhatók, ezért a megoldás lényegesen egyszerübb és áttekinthetőbb. 


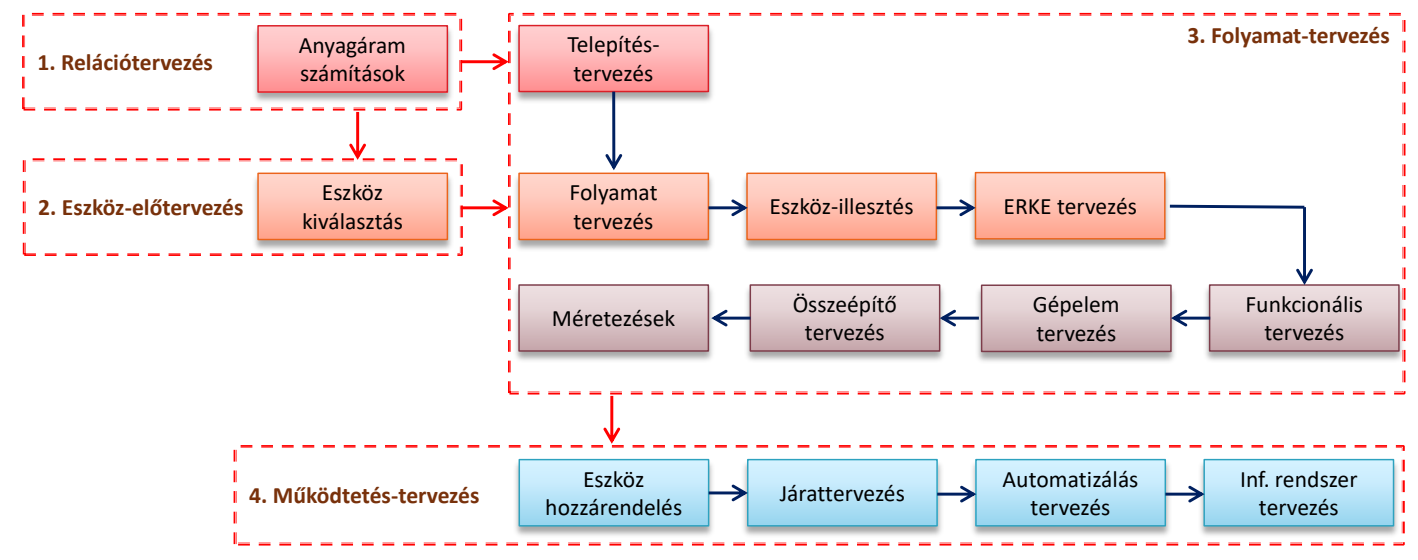

4. ábra. A folyamat alapú tervezés elemei.

A tervezési folyamat legbonyolultabb fázisa a folyamattervezés, ami a már kifejlesztett tervezési módszerek integrálásával jelentősen egyszerüsíthető (5. ábra).

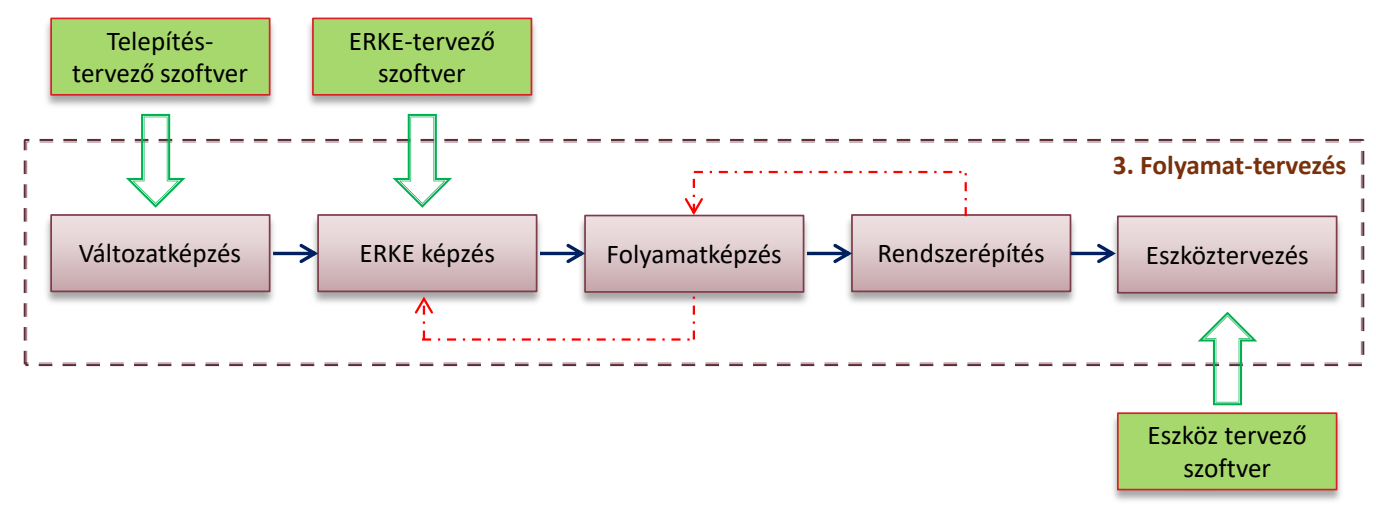

5. ábra. A tervezési módszerek kapcsolása az algoritmushoz.

\section{Folyamat alapú tervezéssel kapcsolatos eredmények}

Ahhoz, hogy a folyamat alapú tervezés, mint gyakorlati módszer alkalmazható legyen mind a négy tervezési fázist ki kell fejleszteni és a müködésüket összekapcsolni. Az elmúlt években az első három fázissal foglalkoztunk.

\subsection{Relációtervezés}

A relációtervezés megvalósítására kifejlesztettünk egy Microsoft Excel VBA alapú alkalmazást (MHRelCalc), aminek 2.0 verziója jelenleg tesztelés alatt van (6. ábra).

A program algoritmusa a gyártási folyamat jellemzőiből (gyártó objektumok, gyártmányok, alkatrészek, termékek jellemzői és kapcsolataik) elóállítja a kiszolgálás során megvalósítandó anyagáramlási kapcsolatok jellemző paramétereit (kapcsolódó objektumok, áramló anyagok, mennyiségek).

A kutatásokat bemutató publikációk összefoglalják a módszer elméleti alapjait [12], a program algoritmusát [15] és felhasználói felületét [16], valamint példákon keresztül szemléltetik a müködését. 


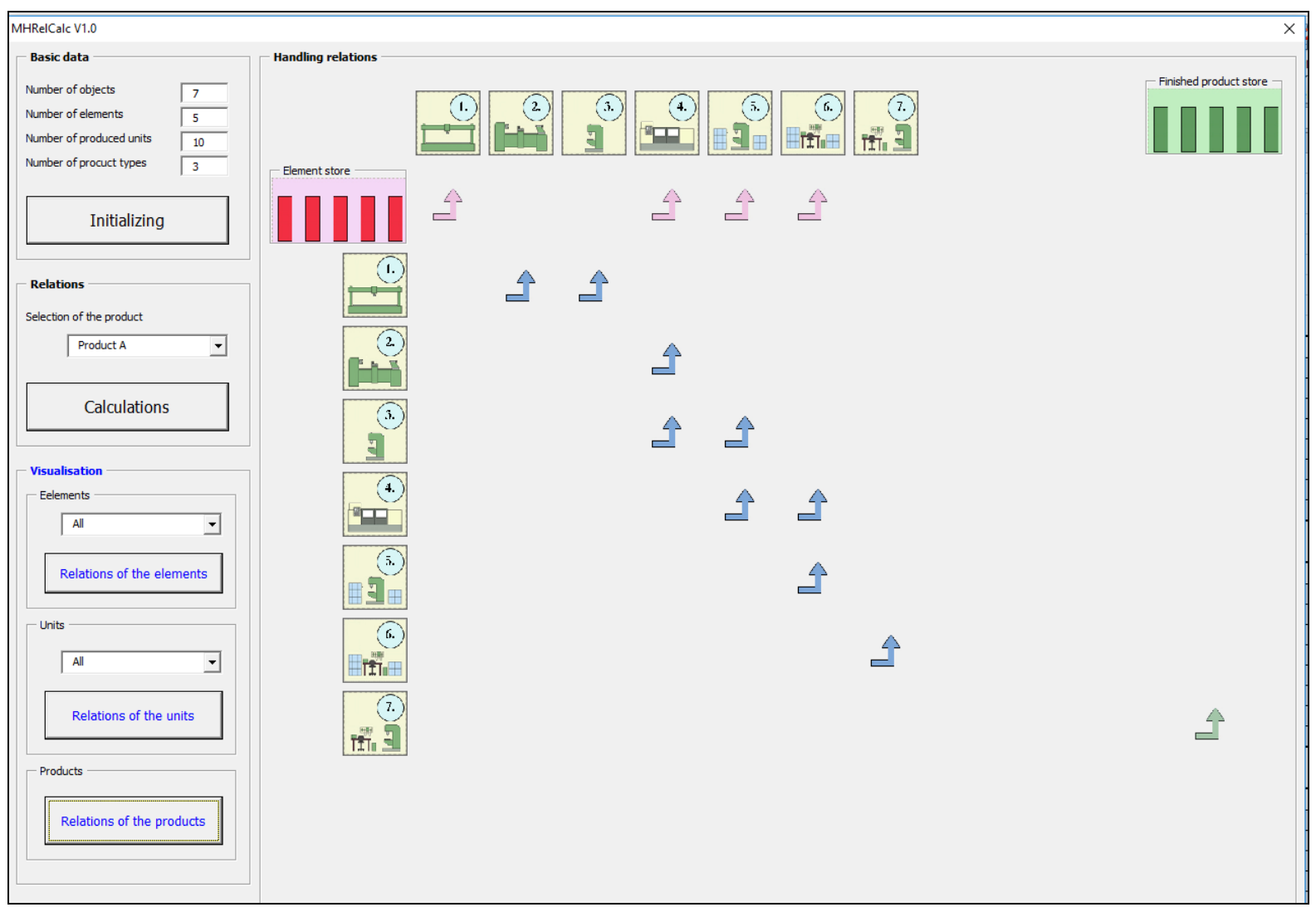

6. ábra. Az MHRelCalc V1.0 szoftver felhasználói felülete [16].

\subsection{Eszköz-elötervezés}

Az eszköz-előtervezés koncepciója úgy egyszerüsíti a tervezést, hogy kiemeli az anyagmozgató eszközök kiválasztását az integrált tervezési folyamat elemei közül, így az integrált lépéseket csak néhány eszközváltozatra kellett végrehajtani.

Az eszköz-elötervezéshez szükséges anyagmozgató gép jellemzök vizsgálata jelenleg is folyik, amely alapján eszköz-specifikus eljárások dolgozhatók ki.

A kutatásokat bemutató publikációk összefoglalják a módszer elméleti alapjait [6], a tervezési jellemzők szerepét a kiválasztási folyamatban (7. ábra) [10], és alkalmazási lehetőségeiket szakaszos kiszolgáló eszközök esetén [17, 18].

\subsection{Folyamat-tervezés}

Az EFOP-3.6.1-16-2016-00011 jelü projekt támogatásával megkezdtük a folyamat-tervezési fázis részletes vizsgálatát, az eddig elért eredményeket 2019-ben publikáltuk [14].

A folyamattervezés az anyagáramlási relációk adott logikán alapuló összekapcsolását jelenti, amely figyelembe veszi az alkalmazható kiszolgáló berendezések, ill. a technológiai folyamatok sajátosságait is. 


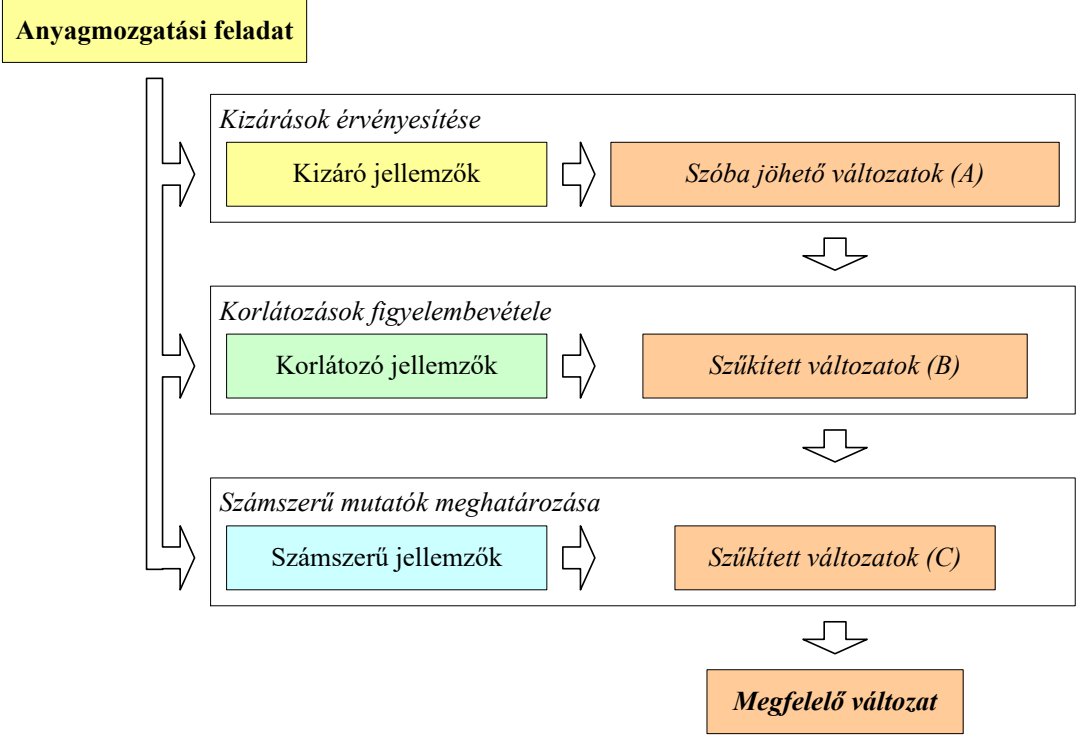

7. ábra. Az eszköz-elötervezés algoritmusa [10].

Az eddigi kutatások elsősorban a folyamattervezés első lépésével, a változatképzéssel foglalkoztak. A változatképzés célja olyan reláció-csoportok létrehozása, amely adott kiszolgáló berendezésekkel megvalósíthatók. Az egyes relációk csoportokba sorolását különböző stratégiák mentén végezzük, amelyek eltérő célokat követnek pl. eszköz-homogenizálás (8. ábra), domináns eszközök keresése, eszköz kiegyenlítés, stb. A változatképzés eredménye egy olyan halmaz besorolás, amelyik minden relációhoz egy konkrét kiszolgáló eszközt rendel hozzá.

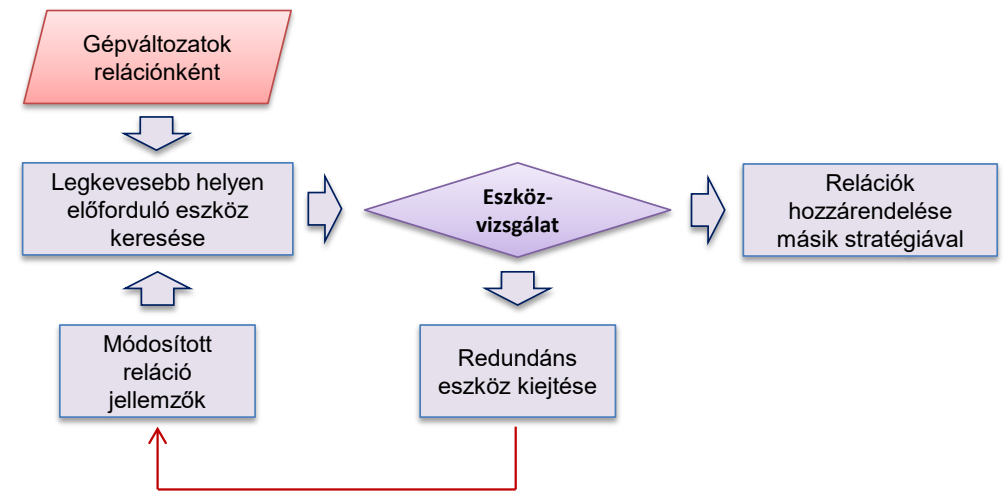

8. ábra. Az eszköz-homogenizálás algoritmusa a változatképzéshez [14].

\subsection{Aktuális kutatások}

Természetesen, a folyamat alapú tervezéssel kapcsolatos kutatások jelenleg is folyamatban vannak, az eddigi eredmények felhasználásával három irányban folytatódik a munka:

- Az eszköz-előtervezéshez szükséges anyagmozgató gép jellemzők vizsgálata során igyekszünk olyan jellemzö-csoportokat alkotni, amelyekkel megkönnyíthetjük a kiválasztási folyamatot. 
- A változatképzés vizsgálata tovább folytatódik, ahol elsősorban a stratégiák hatásaival foglalkozunk.

- Megkezdtük a folyamatépítés vizsgálatát, ahol jelenleg szimuláció alkalmazásával elemezzük a lehetséges változatokat, ill. a képzési folyamatot.

\section{5. Összefoglalás}

Az anyagmozgató rendszerek tervezése bonyolult feladat, aminek oka elsősorban a kiszolgálási változatok és a kiszolgált technológiák sokféleségében, ill. a sztochasztikusan változó kiszolgálási igényekben rejlik. A logisztikus szakemberek számos módszert alkalmaznak a tervezés megvalósítására, de egyik sem ad általános megoldást. A legáltalánosabb és minden magában foglaló megoldás az integrált tervezés lenne, de ez bonyolultsága miatt jelenleg nem realizálható.

A cikkben ismertetett kutatás egy olyan általános tervezési séma kidolgozását célozza meg, amivel a tervezési problémát egyszerüsíteni lehetne, megnyitva az utat az integrált tervezési folyamat alkalmazása előtt. A folyamat alapú anyagmozgatás tervezési algoritmus az integrált tervezési folyamat lépéseit felhasználva próbál egy áttekinthetőbb, kevésbé komplex megoldási sémát megvalósítani.

A folyamat alapú tervezés négy tervezési fázist tartalmaz, amiből az elmúlt években az első hárommal kapcsolatban végeztünk kutatásokat. A relációtervezés megvalósítására kifejlesztettünk egy Microsoft Excel VBA alapú alkalmazást (MHRelCalc), az eszköz-elötervezéshez szükséges anyagmozgató gép jellemzők vizsgálata jelenleg is folyik, az EFOP-3.6.1-16-2016-00011 jelü projekt támogatásával megkezdtük a folyamat-tervezési fázis részletes vizsgálatát.

A koncepcióval kapcsolatos kutatások következő lépése a folyamatépítés szimulációval történő vizsgálata, aminek eredményei hamarosan publikálásra kerülnek.

\section{Köszönetnyilvánítás}

A cikkben ismertetett kutató munka az EFOP-3.6.1-16-2016-00011 jelü „Fiatalodó és Megújuló Egyetem - Innovatív Tudásváros - a Miskolci Egyetem intelligens szakosodást szolgáló intézményi fejlesztése" projekt részeként - a Széchenyi 2020 keretében - az Európai Unió támogatásával, az Európai Szociális Alap társfinanszírozásával valósul meg.

\section{Irodalom}

[1] Telek, P.: Anyagmozgató rendszerek korszerü tervezési módszerei. Gépgyártás 57 No. 1-2 (2018) pp. 70-77.

[2] Bányai T.: Integrált anyagáramlási rendszerek strukturált modellezése. Gép 63 No. 4 (2012) pp. 83-86.

[3] Antoniolli I.; Guariente P.; Pereira T.; Pinto Ferreira L.; Silva F. J. G.: Standardization and optimization of an automotive components production line. Procedia Manufacturing 13 (2017) pp. 1120-27. https://doi.org/10.1016/j.promfg.2017.09.173

[4] Cselényi J.; Illés B. (szerk.): Anyagáramlási rendszerek tervezése és irányítása I. Miskolci Egyetemi Kiadó, Miskolc (2006)

[5] Ortner-Pichler A.; Landschützer C.: Improving geometry manipulation capabilities of Knowledge-based Engineering applications by the versatile integration of 3D-CAD systems. In CD proc. of MultiScience - XXXI. microCAD Int. Multidiscipl. Sci. Conf. (C1: 3.), University of Miskolc (2017) https://doi.org/10.26649/musci.2017.044 
[6] Telek P.: Equipment preselection for integrated design of materials handling systems. Advanced Logistic Systems - Theory and Practice 7 No. 2 (2013) pp. 57-66.

[7] Telek P., Cservenák Á.: Planning of material handling - literature review. Advanced Logistic Systems - Theory and Practice 13 No. 2 (2019) pp. 29-44. https://doi.org/10.32971/als.2020.0003

[8] Iris F.A. Vis: Survey of research in the design and control of automated guided vehicle systems, European Journal of Operational Research, 170, No. 3 (2006) pp. 677-709. https://doi.org/10.1016/j.ejor.2004.09.020

[9] Welgama P. S.; Gibson P. R.: A Hybrid Knowledge Based/Optimisation System for automated Selection of Materials Handling System. Computers \& Industrial Engineering, 28 No. 2 (1995) pp. 205-17. https://doi.org/10.1016/0360-8352(94)00200-7

[10] Telek, P.: Anyagmozgató gépek tervezési jellemzői. In: Kékesi, Tamás (szerk.) 28th microCAD Nemzetközi Multidiszciplináris Tudományos Konferencia $=28$ th microCAD International Multidisciplinary Scientific Conference Miskolc (2014) Paper: C1, No. 10 , 6 p.

[11] Telek, P.: Computer Design of Materials Handling Equipment. In: The Publications of the MultiScience - XXIX. microCAD International Multidisciplinary Scientific Conference Mis-kolc, (2015) Paper: C1_4 , 7 p. https://doi.org/10.26649/musci.2015.030

[12] Telek, P.: Material flow relations in the design process of materials handling. Advanced Logistic Systems - Theory and Practice 10 No. 1 (2016) pp. 53-64.

[13] Telek, P.: Process-based planning of material handling in manufacturing systems. IOP Conference Series: Materials Science and Engineering 448, 012018. (2018) https://doi.org/10.1088/1757-899X/448/1/012018

[14] Telek, P.: Folyamat-képzés az anyagmozgatás-tervezésben. Gépgyártás 58 No. 1-2. (2019) pp. 57-63.

[15] Telek, P.: Computer algorithm for determination of material flow relations. Advanced Logistic Systems - Theory and Practice 10 No. 2 (2016) pp. 71-78.

[16] Telek, P.: Computer Method for the Determination of Materials Handling Relations. In: Kékesi, Tamás (szerk.) MultiScience - XXXI. microCAD International Multidisciplinary Scientific Conference Miskolc (2017) Paper: C1_5 , 9 p. https://doi.org/10.26649/musci.2017.046

[17] Telek, P.: Application of device-preselection for discontinuous unit handling. Advanced Logistic Systems - Theory and Practice 8 No. 1 (2014) pp. 93-102.

[18] Telek, P.: Serving times of discontinuous materials handling machines. Advanced Logistic Systems - Theory and Practice 8 No. 2 (2014) pp. 87-96. 